\title{
Amendment of India Mauritius DTAA and its Impact on Foreign Investment in India
}

\author{
B. K. Pandey
}

\begin{abstract}
The objective of this paper is to the study the impact of the amendment of India Mauritius DTAA on foreign investment in India. It provides adetailed analysis of how Mauritius, a small island country became the most favourite route for foreign investor in India during the period 2000 to 2017. The paper identifies the reasons for emergence of Mauritius as the foremost exporter of foreign capital to India and in this context examines the role of the Agreement on Avoidance of Double Taxation and the Prevention of Fiscal Evasion with respect to Taxes of Income and Capital Gains between India and Mauritius (DTAC).

In 2016, DTAC was amended and with the implementation of General Anti Avoidance Rule (GARR) from 2017 by India and changes in international taxation zeitgeist due to $O E C D$ project on Base Erosion Profit Shifting (BEPS) the Mauritius route faced new challenges. The paper studies the influence of these changes on FPI and FDI investments flow from Mauritius to India.It finds that advantage of Mauritius in FDI and FPI flow has come down in 2018-19 and its share in foreign investment is likely to come down further with the amendment of the DTAC taking full effect from April 2019. However,amendment has given Mauritius a competitive advantage in channelizing debt investment to India as compared to its competitors like Singapore and the Netherlands and in future we may see higher debt investment from Mauritius.

Keywords : DTAA, International Taxation, Tax Treaty, FDI/FPI flow to India
\end{abstract}

\section{INTRODUCTION}

Mauritius in the last 15 years became a popular route to direct any investment in India more so in the case of FDI, where it has a lion's share until the amendment of the India Mauritius tax treaty in 2016 ( Jaiswal 2018). Between April 2000 and March 2019, India received $\$ 420$ billion of Foreign Direct Investment (FDI) and Mauritius contributed a phenomenal \$134 billion, 32 percent of the total FDI inflows to India in this period. The other four countries in the list of largest sources of FDI to India are Singapore ( $\$ 83$ bn or 20 percent), Japan ( $\$ 30$ bn or 7 percent), the UK ( $\$ 26$ bn, or 6 percent), the Netherland (\$27 billion and 7\%) and the USA ( $\$ 25$ bn or 6 percent). In Foreign Portfolio Investment(FPI), the share of Mauritius was $20 \%$ until April 2016. Hence, approximately half of the FDI and roughly a quarter of FPI was associated to Mauritius and Singapore (DPII, 2019). Table 1 below shows FDI in to India from top 10 countries:

Revised Manuscript Received on July 22, 2019

B.K.Pandey, Adjunct Professor, NIFM, Faridabad, Haryana, India.
Table 1 Country-Wise FDI Equity Inflows to India from April 2000 to March 2019 (US\$ Billion)

\begin{tabular}{|c|c|c|}
\hline $\begin{array}{c}\text { Source / } \\
\text { Industry }\end{array}$ & $\begin{array}{c}\text { Cumulative FDI } \\
\text { flows } \\
\text { into India } \\
(2000-2019): \\
\text { Amount of Foreign } \\
\text { Direct Investment } \\
\text { Inflows }\end{array}$ & $\begin{array}{c}\text { \%age to } \\
\text { total } \\
\text { Inflows }\end{array}$ \\
\hline Grand Total & $\mathbf{4 2 0 . 1 4}$ & \\
\hline Mauritius & 134.47 & 32.01 \\
\hline Singapore & 82.99 & 19.76 \\
\hline Japan & 30.27 & 7.21 \\
\hline Netherlands & 27.35 & 6.51 \\
\hline United & 26.79 & 6.38 \\
\hline Kingdom & 25.56 & 6.08 \\
\hline USA & 11.71 & 2.79 \\
\hline Germany & 9.87 & 2.35 \\
\hline Cyprus & 6.65 & 1.58 \\
\hline UAE & 6.64 & 1.58 \\
\hline France & & \\
\hline
\end{tabular}

Source: Source: Dep't of Promotion of Industry and Internal Trade, Ministry of Commerce \& Industry, Fact sheet on FDI India and Mauritius signed a Protocol to modify their 3 decade old tax treaty in May 2016 which caused important changes in international investment strategy. Although the change was not abrupt and unexpected, the amendment is significant for foreign investors using Mauritius route forcing them to review and reassess their structures and strategy of investment.

This paper aims to find out why Mauritius emerged as the most favourite route for foreign investment in India and what is the impact of the amendment to India Mauritius DTAAon the foreign investment from Mauritius. The paper is divided in to three sections.

Section I analyses the resaons for emergence of a small country like Mauritius as the biggest investor in India. In this context, it discusses the features of DTAA between India and Mauritius signed in 1982.

Section II analyseswhy India wanted revision of the Double Tax Avoidance Treaty between India and Mauritius (DTAC) and highlightsthe key amendments to (DTAC) for which a protocol was signedin May 2016 It discusses the BEPS (Basic Erosion and Profit 
Shifting) project of OECDand India's implementation of GAARfrom April 2017, which were the triggers for the May 10, 2016 Protocol. It analyses the how these amendments are likely to affect FPI and FDI investments from Mauritius to India.

Section III examines what has been the impact of these amendments on foreign investment flow from Mauritius in the last two years. It assess the impact in the last two years and what is the future prospect of inflows given that the full impact of the amendments will take effect from April 2019. From the analysis, it emerges that at present after the amendment the advantage of the Mauritius route lies especially in channelling debt investment to India while its advantage in equity investment has come down in recent years especially in 2018-19.

\section{Section I}

\section{Reasons for the popularity of Mauritius Route}

There are multiple of reasons, commercial as well as tax-driven for investing in India from Mauritius. Mauritius emerged as the leading exporter of foreign investment due to the following reasons:

\section{India-Mauritius Double Tax Avoidance Treaty:}

One of the main reasons for the popularity of Mauritius route was the Convention for the Avoidance of Double Taxation and the Prevention of Fiscal Evasion with Respect to Taxes of Income and Capital Gains (DTAC) between India and Mauritius signed in $1982^{1}$.Mauritius gained from the liberal and unique terms of the treaty for over 30 years until it was amended in 2016 ( Business Line 2015)

\section{Modus Operandi of Mauritius Route}

The India-Mauritius tax treaty (DTAC) signed in 1982 granted an absolute protection to Mauritian residents from tax for capital gains earned from India. DTAC granted taxing rights to Residence state only and no capital gains to India as Source state. As per Article 13(4) of the DTAC, on the sale of the shares in the Indian company, there would be no Indian capital gains tax imposed on the seller. The investor first establishes an intermediary firm in Mauritius, then sends the capital to that firm and finally invest in India

${ }^{1}$ Convention for the Avoidance of Double Taxation and the Prevention of Fiscal Evasionwith Respect to Taxes of Income and Capital Gains art. 28, India-Mauritius, Aug. 24, 1982, Notification No. G.S.R. 920(E) (June, 12, 1983) (available for downloadat http://www.aseanbriefing.com/userfiles/resources-pdfs/India/ DTA/Asia_DTA_Mauritius_India.pdf)

through that firm. The investors from non-treaty countries would initially send funds to Mauritius, acquire the character of a Mauritian resident and thereafter invest from Mauritius to India.

\section{Treaty Shopping}

This phenomenon of routing of investment through a third country is known as the treaty shopping. In treaty shopping, cross-border capital/investment flows are routed through a third country through creation of shell companies merely to take advantage of the treaties of that jurisdiction. And shell companies are firms that don't engage in any real business/economic activity, but are merely used by the owner/controller to carry out financial/legal works.

Since this benefit of "no capital gains tax on the investments in India' was available only to the residents of Mauritius, investors from other countries would first create a shell company in Mauritius, and take the legal identity as a Mauritian resident. This way, even a non-Mauritian investor could own a company with Mauritian identity with little extra cost, and then this company could be used to route the investment to India, and enjoy the benefits available to the Mauritian company. The tax treaty didn't distinguish between a company that was actually functioning in Mauritius versus a company that was only established there to get tax benefits. So for a few thousand dollars, one can become a Mauritius entity and invest through it into Indian stocks and shares, and escape from paying capital gains taxes either in India or Mauritius (Adrienne (2018).

\section{Round Tripping}

This method was so beneficial and popular that even Indian investors would first take their funds out of the country, and then bring them back in the form of foreign investment through these countries. This process is known as Round Tripping.

By treaty shopping and round tripping, the investors from Mauritius route enjoyed following two tax benefits:

(a)No Capital Gains Tax: Both in India and Mauritius

(b) Low Dividend Tax: In comparison, the Dividend tax can be of up to $15 \%$ in Cyprus or $18 \%$ in Singapore which were 
other jurisdiction used by investors for investing in India.

\section{Domestic Tax Regulations of Mauritius}

Apart from the tax treaty advantage, Mauritius also had very low domestic tax rate. Since Mauritius did not levy tax on capital gains or any withholding tax on dividend or interest derived from the global investment derived by Global Business Companies (GBC) in Mauritius, it emerged as a leading tax planning destination.

\section{Presence of Global Business Companies (GBC)} in Mauritius

Mauritius launched its global business sector and also allowed formation of GBC and destination of choice to structure investment in emerging markets like India. There were two categories of Global Business Licenses issued by Financial Services Commission of Mauritius till 2018.

GBC1 are treated as tax residents of Mauritius, eligible to avail benefits of Mauritius' network of tax treaties, while GBC2 are not treated as tax residents of Mauritius and are not eligible to avail benefits of Mauritius' network of tax treaties. GBC2 are not liable to tax in

In Mauritius, Corporate tax rate is $15 \%$. GBC1 were eligible to obtain deemed tax credit for the actual foreign tax incurred on income or; a deemed foreign tax credit equivalent to $80 \%$ of the Mauritius tax payable. Hence, the effective tax rate comes between 0-3\% (Bloomberg Quint, 2018) Thus, .Mauritius combined the advantages of an offshore jurisdiction, no capital gain taxes, no withholding taxes, confidentiality and easy repatriation of profits and capital and all these factors helped Mauritius to consolidate its position as major off shore financial sector (ODI, 2017)..

\section{Network of DTAAs}

Mauritius is a treaty basedjurisdiction. It has signed 44 tax treaties developed itself as off shore financial centre with the help of one of the best network of DTAA treaties especially in Africa. Mauritius has a large network of 46 tax treaties and is in process to negotiate more such treaties (Wolters Kluwer, Low Tax and Business Portal 2019).

\section{Network of BITs}

In addition to the Tax treaties, the wide network of Bilateral Investment Protection Treaties (BIT) signed by Mauritius is also an important benefit available to Mauritius based companies. Mauritius and India have a BIT which provides various rights to Mauritius based entities( Withersworldwide 2016).

6. Historical Relation with India and presence of Indian Diaspora in Mauritius

Another important factor in favour of Mauritius is its historical and cultural association with India which forms the basis of an exceptionally close association between the two countries. Indian Diaspora in Mauritius constitutes about 68\% of Mauritius population and has been politically powerful. India's soft corner for Mauritius due to Indian Diaspora is reflected in giving special provisions in favour of Mauritius in DTAC.

\section{Comparative advantage of Mauritius}

The strategic position of Mauritius, its business-constructive framework, its ethnicity, its connectivity and openness to the rest of the world made Mauritius an attractive centre for raising and pulling of capital and financial services, linking Asia/Europe/USA to Africa. The combination of all these factors has contributed to the positioning of Mauritius as a world class international financial centre .Thus, Mauritius became a popular option for investors to route their investments into India.

\section{Section II}

\section{Why India wanted a change in DTAC}

There was a lot of political and public pressure to plug what was perceived as tax loophole. India was worried as the treaty had resulted in loss of revenue to India. It was suspected that funds that escaped taxation in India may have been laundered abroad and were making its way back to India through Mauritius-resident entities in the guise of foreign direct investment (FDI). There was massive treaty abuse as non- treaty countries enjoyed the benefit as no Limitation of Benefit (LOB) clause was in the DTAC. The Capital Gains Tax exemption was not subject to any expenditure threshold, 'substance' or limitation criteria. It also led to Double Non-Taxation as companies neither paid taxes in India nor in Mauritius. If you were to sell shares of an Indian entity, capital gains tax was payable. On the contrary if the shares of the holding entity in Mauritius were to be sold, itwas exempt from capital gains tax both in India and in Mauritius. Mauritius became a "tax haven" for investments. Both "foreign" and "domestic" (routed through Mauritius jurisdiction) investment entered freely into India. It became a route for bringing in black money, terror funds and 'round tripped' money. 


\section{GAAR from 2017}

India's primary focus is to check double non taxation and illegitimate tax planning. With this in view, India announced its commitment to implement GARR from April 2017. GAAR gives the Indian authorities powers to scrutinise transactions structured primarily in such a way as to deliberately avoid paying tax in India. The tax authorities will look in to commercial substances rather than mere form of the arrangement. The announcement of GAAR pushed Mauritius to agree for revision of the treaty.

\section{Ratification of the Multilateral Convention to Implement Tax Treaty Related Measures to Prevent Base Erosion and Profit Shifting}

BEPS project which gained momentum after 2013 also induced Mauritius to agree for revision of the treaty India ratified the Multilateral Convention to Implement Tax Treaty Related Measures to Prevent Base Erosion and Profit Shifting on 07/06/2017. Convention is one of the results of the OECD/G20 BEPS project to tackle base erosion and profit shifting. The Convention enables countries to implement the tax treaty related changes to achieve anti-abuse BEPS outcomes through the multilateral route.

\section{Amendment of DTAC in 2016}

After a decade of negotiations, the change in the treaty came in May 2016, allowing India to tax capital gain that Mauritius-resident firms made in India. India also amended its DTAAs with Singapore and Cyprus by December 2016..The amendments changed the provision on capital gains, which was the main motivation behind the routing of investment through Mauritius. The features of amendments are:

\section{Main consequences of the Amendment}

(i)India gets right to tax capital gain tax:(i) The Protocol gives India the right to tax capital gains on transfer of shares of an Indian company acquired on or after 1 April 2017.

(ii) Grandfathering of existing investment: Capital gains arising from the alienation of shares of an Indian company acquired prior to 1 April 2017 shall be exempt from tax in India, irrespective of when they are sold.

(iii)Transition period: The Protocol provides for a two year transition period up to 31 March 2019. Capital gains arising from the alienation of shares acquired on or after 1 April 2017 and sold by 31 March 2019 (Transition Period), shall be taxed in India at a rate not exceeding $50 \%$ of the tax rate applicable in India, at the point in time of gain recognition. However, this $50 \%$ rebate is offered only if certain terms of the Limitation of Benefits (LOB) are fulfilled
(iv)After 31 March 2019, tax will be charged at full domestic tax rates,

(iv) Capital gains on derivatives and fixed income securities will continue to be exempt. It is important to note that taxation of capital gains from securities (including debentures) and other capital assets alienated stay unaffected..

\section{(vii)Lower withholding tax on Debt:}

The Prootocol provides that the interest arising in India to Mauritian resident banks will be subject to withholding tax in India at 7.5 per cent after March 31, 2017.

(viii) Limitation of Benefits clause for availing concessional rate of taxation during the transitional period

The protocol provides for a Limitation of Benefits clause for availing concessional rate of taxation during the transitional period. The LOB provisions have both Purpose \& Business test for the companies to meet and the company a shall not be entitled to the benefits of $50 \%$ lower tax rate, if its affairs were arranged with the main purpose to take advantage of the such $50 \%$ lower tax rate in the Treaty. Therefore, business entities must have bona fide business activities to avail of the said lower rate. Similarly, shell or conduit companies, viz., resident legal entities with negligible business operations, without any real or continuous business activities are not entitled from availing the lower tax rate during the Transition Period ${ }^{2}$.

The LOB provisions also mandated for fulfilling the Expenditure test which is as follows:- Companies with an expenditure (in the residence State) of less than Indian Rupees 2,700,000 (in case of an Indian resident) or Mauritian Rupees $1,500,000$ (in case of a Mauritian resident) in the immediately preceding period of 12 months from the date the gains arise, will be deemed to be shell or conduit companies, unless they are listed on a recognised stock exchange (in the residence State).Therefore, according to the LOB provision, in addition to satisfying the expenditure test, companies must also satisfy the Purpose Test.

\section{(ix)Service Permanent Establishment:}

The definition of a Permanent Establishment (PE) as provided in Article 5 of the Treaty shall now include an additional category of service PE. This PE clause shall be triggered by the furnishing of services (including consultancy services) through employees or other personnel engaged by

${ }^{2}$ Department of Revenue, Government of India (2016)" Protocol Amending the Convention for the Avoidance of Double Taxation and the Prevention of Fiscal Evasion with Respect to Taxes on Income and Capital Gains, India-Mauritius ,May 10, 2016, Notification No. S.O. 2680(E) (Aug. 10, 2016).

\section{Published By:}


an enterprise for a period or periods aggregating more than 90 days within any 12 month period.

\section{(x)Fees for Technical Services}

In addition to the provision relating to income from 'royalties', a new provision dealing with 'Fees for Technical Services' (FTS) has been introduced whereby FTS arising in a State (say India) and paid to a resident of other State (say Mauritius) is now taxable in both States (India as well as Mauritius). However if the beneficial owner of the FTS is a resident of the other State, then a tax of $10 \%$ shall be charged on the gross amount of FTS. Additionally, if the FTS paid exceeds the amount that independent parties would have agreed upon, such excess would continue to be taxed as per the laws of each State. This insertion provides clarity on how technical services rendered by companies shall be taxed in light of the past issues surrounding whether tax should be withheld in India.

\section{(xi) Taxation of 'Other Income':}

A non-obstante clause has been included whereby income not dealt with expressly in the Treaty, may be taxed in the source State (i.e. India, for inbound investments). This alters the current distribution of taxing rights, wherein the residuary category of 'other income' allows only the resident State to tax such income.

\section{(xii) 'Exchange of Information' (EOI):}

The Protocol introduces the current provisions with a detailed EOI provision whereby, competent authorities of India and Mauritius shall exchange information as is reasonably foreseeable treating such information as secret. However, the Protocol enables the information to be disclosed in public court proceedings. Additionally, EOI provision now requires India and Mauritius to use its information gathering measure even in the absence of domestically requiring the information sought by the other State. Similar to the extant India Singapore tax treaty, bank secrecy, information held by agent or nominee in fiduciary capacity shall not hinder the supply of information requested.

\section{(xiii) Assistance in Collection of taxes.}

An additional provision is also provided detailing the mechanism for the Assistance in Collection of taxes.

\section{Section III}

\section{Impact of Amendment on Investment Flow}

The amendments are likely to help in resolving the issue of round tripping and treaty shopping for India. However, investment flow to India from Mauritius is to be affected to some extent.

\section{Decline in Foreign Investment Flow from Mauritius:}

Mauritius route started losing its attraction due to uncertainty during the negotiation period of the treaty. About 39.6\% of FDI to India came from Mauritius between 2001 and 2011.
From 2011 to 2017, during the period of negotiation, its share in cumulative investment came down from 44 to $36 \%$. Indonesia revoked its double taxation avoidance treaty with Mauritius mentioning 'tax treaty abuse' as the reason in 2004 Anxieties that India may take similar action, or try for an amendment to make it more perfect, induced investors to look at other routes.

Another reason why the Mauritius conduit became less attractive was the imminent implementation of the General Anti-Avoidance Rule (GAAR) in April 2017, which aims to plug tax avoidance. Under these rules, Indian I-T authorities can take a closer look at 'brass-plate companies' that have been set up in offshore centres solely to evade tax. Thus announcement of GAAR) and possible re-negotiation of the tax avoidance treaty, FDI inflows from Mauritius started declining. FDI investors started shifting their loyalty to Singapore. In 2013-14 and 2015-16, Singapore edged out Mauritius. In 2015-16, its share in FDI came down to US dollar 8 bn as compared to US dollar 13.7 bn from Singapore.

Mauritius-based investors' holdings in FPI also came down from 26 per cent of FPI assets in 2012 to $14 \%$ by the end of 2018. The investors from the US account for the largest share 35.7 per cent of the total FPI currently. While Portfolio investors from Singapore, Luxembourg and United Kingdom maintained their share over the past four years. Share of the obscure Participatory Notes has declined from more than 50 per cent of FPI assets to 2.4 per cent due to higher disclosure requirements and clamp-down on opaque structures. Singapore is also a low-tax jurisdiction and an offshore financial centre. But India's double tax treaty with Singapore was more fool proof, with a Limitation of Benefit clause that checks treaty abuse provided more confidence to investors.

\section{Mauritius Route after the Amendments/GAAR/BEPS}

Investments from Mauritius were impacted by the changes in the treaty, implementation of GAAR from April 2017 and BEPS ratification by India. Until 2017-18, Mauritius was the top source of FDI into India with $\$ 13.41$ billion investments, followed by Singapore, although its share in total investment came down. Total FDI stood at $\$ 37.36$ billion, a marginal rise over the $\$ 36.31$ billion recorded in 2016-17.

Investors who were using the Mauritius route begun routing their investments through other channels with the benefits getting phased out. As a consequence, Singapore replaced Mauritius as the top source of foreign investment into India in $2018-19$, accounting for $\$ 16.22$ billion inflows, whereas only $\$ 8$ billion FDI came from Mauritius. It downsized nearly to half of its flow in 2017-18 from US \$ 15.9 bn to US $\$ 8.84$ billion in 2018-19. Correspondingly, FDI from Singapore surged by over 36 percent in 2018-19.

The main cause for the downslide was abrogation of capital gain tax benefit under the new DTAC. The other major investors in the country
includes Japan, the
Netherlands, the United
Published By:
Blue Eyes Intelligence Engineering Exploring innovation
\& Sciences Publication 
Kingdom (UK), the United States (US), Germany, Cyprus, the United Arab Emirates (UAE) and France. According to the latest data of the Department for Promotion of Industry and Internal Trade (DPIIT), FDI in 2017-18 was $\$ 44.85$ billion. FDI in India declined for the first time in the last six years in $2018-19$, falling by 1 per cent to $\$ 44.37$ billion as shown in the table below:

Table 2: Share of Top Investing Countries FDI Equity Inflows in India (Financial Years): Country-Wise

(US\$ Billion)

\begin{tabular}{|l|l|l|l|}
\hline Source / Industry & $\mathbf{2 0 1 6 - 1 7}$ & $\mathbf{2 0 1 7 - 1 8}$ & $\mathbf{2 0 1 8 - 1 9}$ \\
\hline Total FDI & 43.478 & 44.857 & 44.366 \\
\hline
\end{tabular}

\section{Country-Wise Inflows}

\begin{tabular}{|l|l|l|l|}
\hline Mauritius & 15.728 & 15.941 & 8.084 \\
\hline Singapore & 8.711 & 12.180 & 16.228 \\
\hline Japan & 4.709 & 1.633 & 2.965 \\
\hline Netherlands & 3.367 & 2.800 & 3.870 \\
\hline United Kingdom & 1.483 & 0.847 & 1.351 \\
\hline USA & 2.379 & 2.095 & 3.139 \\
\hline Germany & 1.069 & 1.124 & 0.886 \\
\hline Cyprus & 0.604 & 0.417 & 0.296 \\
\hline UAE & 0.675 & 1.050 & 0.898 \\
\hline France & 0.614 & 0.511 & 0.406 \\
\hline
\end{tabular}

Source: Source: Dep't of Promotion of Industry and Internal Trade, Ministry of Commerce \& Industry, Fact sheet on FDI

\section{Foreign Direct Investment in India (in \$ billion)}

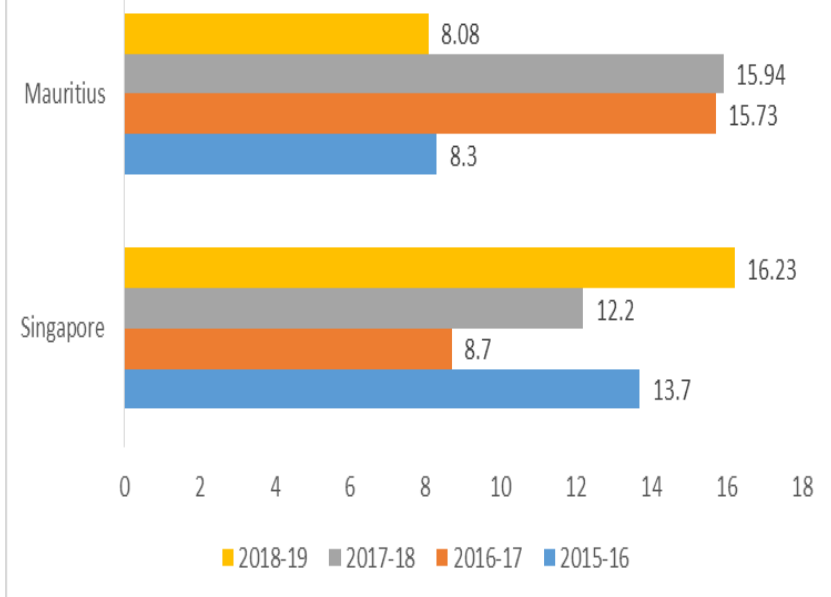

Figure 1

\section{WHAT NEXT FOR MAURITIUS?}

The revision of the treaty has definitely dented Mauritius supremacy but there are favourable elements that still make Mauritius a smart jurisdiction. In view of the amendments, the investment strategy are being revisited and also because of the introduction of GAAR and due to the amendments in the DTAA, both effective from 1 April 2017. Foreign investors that have made investments or are doing business in India are reviewing their existing structure and investment modes to consider whether they are adequately robust to bear up the challenge under anti-avoidance rules and taxation of capital gains. Depending on investment strategies, companies are weighing up the whether to go for portfolio or direct, debt or equity, and factoring out Indian taxes as a cost of doing business in India.

It is to be noted that the amendment to the India-Mauritius treaty affects equity investments only and continuity of benefit to other instruments. It also provides much needed certainty in respect of the India-Mauritius DTAC.

\section{DEBT INVESTMENT:}

One of the options to investors is structuring debt investments. The Protocol provides that all Mauritius entities including banks earning interest income from Indian sources will now be required to pay tax at a rate of $7.5 \%$ of the gross amount of interest provided that the Mauritius entities are the beneficial owners of such interest income. Mauritius is certainly the preferred route for investing in the debt market in India and now emerges as the preferred jurisdiction for debt investments considering the lower withholding tax rates for interest income as well as the capital gains tax exemption, as compared to such other jurisdiction such as Singapore (15\%) and Netherlands $(10 \%)$ as explained in the table below:

Table 3 Indian Withholding Tax on Interest arising on Debt claims or loans

\begin{tabular}{|c|l|c|}
\hline Mauritius & Singapore & Cyprus \\
\hline $7.5 \%$ & $15 \% / 10 \%$ & $10 \%$ \\
\hline
\end{tabular}

Between May 2016 and now, foreign investors have purchased more debt more than equity in Indian capital market and a large part of this is from Mauritius. Investing in debt instruments provides the following incomes from investments in India: 
(i)gains arising from sale / transfer of securities held in Indian companies

(ii) interest income.

The domestic tax rate in Mauritius is $15 \%$. However, global business companies benefit from a deemed foreign credit of $80 \%$, making the effective tax rate a maximum of $3 \%$. The headline rate of tax in Netherlands it is $25 \%$, and in Singapore it's about $17 \%$.Therefore this makes Mauritius a more attractive jurisdiction for debt investment.

\section{MAURITIUS KEEPS DTAC OUT OF MULTILATERAL INSTRUMENT ('MLI')}

Additionally, by keeping DTAC out of MLI, Mauritius has made a smart move. Because the tax treaty with India is not being notified under the MLI, it means that the benefits under the India-Mauritius treaty will not be qualified by the Principal Purpose Test (PPT). It means that treaty benefits with respect to other jurisdictions will require satisfaction of additional conditions which are subjective tests. So, it's relatively risk free to avail the $7.5 \%$ interest withholding cap under the India-Mauritius treaty, which can be subject to some litigation in the case of Netherlands or Singapore.

\section{SAFETY OF INVESTMENT}

Although tax optimization is a key driver in channelizing and choosing investment structures, safety of investment is equally important. Bilateral Investment Protection Treaties (BITs) is a key risk management strategy. Many experts hold that now not much space is left for tax incentivized investment. With the global efforts against erosion of tax base, the space for non-taxation of income has significantly shrunk. The investment protection offered by BITs signed by Mauritius is yet another important justification for using Mauritius jurisdiction.

\section{CONCLUSION}

While there has been significant loss insofar as equity investments are concerned, there will be increased debt based investments that should still flow through Mauritius into India. Further, existing investors are comforted with the fact that their current investments are being grandfathered. Thus, from the above it is clear that while the treaty amendment has taken away the benefits on capital gains, the lower rate on debt investments will act as a comfort and debt based investments will flow to India through Mauritius in larger quantity. Mauritius will remain an important source of foreign investment to India in near future.

\section{REFERENCES}

1. Avi-Yonah, R.S. (2009). "Double Tax Treaties: An Introduction" in Sauvant, K. P., \& Sachs, L. E. (Eds.), the Effect of Treaties on Foreign Direct Investment,(pp. 99-107). Oxford: Oxford University Press.

2. Bloomberg quaint(2018), How the Latest Mauritius Budget Changes Taxation for FPIs into India URL: http://www.globalfinance.mu/how-the-latest-mauritius-budget-changes -taxation-for-fpis-into-india/

3. Bose, Debadatta (2017), 'From Lax to Tax: India's Changing Policy on Overseas Taxation'45 Intertax, Issue 4, pp. 341-352.

4. Burugula Pavan (2019) "Luxembourg, Cayman Islands, Ireland FPIs"e favourite gateways to India", The Economic Times, Feb 2019.

5. Business Line (2016) “ Investment routed from Mauritius to India for tax benefits: WTO"

6. Coutinho Ashley (2018) "Mauritius funds likely to shift to Singapore for India investment", Business Standard, Mumbai, July 10, 2018.

7. Department for Promotion of Industry and Internal Trade (2018) fact sheet on foreign direct investment (FDI) from April, 2000 to September, 2018URL:https://dipp.gov.in/sites/default/files/FDI_FactSheet_1Febru ary2019.pdf.

8. Department of Promotion of Industry and Internal Trade. Fact Sheet on Foreign Direct Investment (FDI). From April, 2000 to March, 2019. (updated up to March 2019).

9. Department of Revenue, Government of India (1983),"Convention for the Avoidance of Double Taxation and the Prevention of Fiscal Evasion with Respect to Taxes of Income and Capital Gains art. 28, India-Mauritius, Aug. 24, 1982, Notification No. G.S.R. 920(E)(June, 12, 1983)" (available for download at http://www.aseanbriefing.com/userfiles/resources-pdfs/India/DTA/Asia DTA Mauritius I India.pdf.

10. Department of Revenue, Government of India (2016)" Protocol Amending the Convention for the Avoidance of Double Taxation and the Prevention of Fiscal Evasion with Respect to Taxes on Income and Capital Gains, India-Mauritius ,May 10, 2016, Notification No. S.O. 2680(E) (Aug. 10, 2016).

11. Department of Revenue, Government of India,(2016) "Protocol Amending the Convention for the Avoidance of Double Taxation and the Prevention of Fiscal Evasion with Respect to Taxes on Income and Capital Gains", May 10, 2016, Notification No. S.O. 2680(E) (Aug. 10, 2016), Accessed on 20 January 2019. URL:http://www.incometaxindia.gov.in/communications/notification/ notification682016.pdf

12. Dave, Sachin (2018) "Singapore, Mauritius fight for relevance after DTAA amendments in 2016" September29, 2018, The Economic Times

13. Desai Nisith (2016) "Mauritius Route Emerges Unscathed: AAR Upholds Relief under the Mauritius Treaty", February

2016.URL:http://www.nishithdesai.com/information/research-and-artic les/nda-hotline/nda-hotline-single-view/article/mauritius-route-emerges -unscathed-aar-upholds-relief-unde

14. Desai,Tejas (2016) “India-Mauritius tax treaty: An end and a new beginning", Forbes India, 7 June, 2016

15. Desai Nisith (2017) "India's_MLI_Positions", 14 June 2017. http://www.nishithdesai.com/fileadmin/user_upload/pdfs/Research_Pa pers.

16. Jaiswal Suraj (2018) "Is Netherlands Becoming the New 'Mauritius Route for FDI Flows Into India? Wire, April 2018.

17. Jaiswal Suraj (2018)" How come Mauritius is the biggest foreign investor in India? Center for budget and governance accountability," Delhi

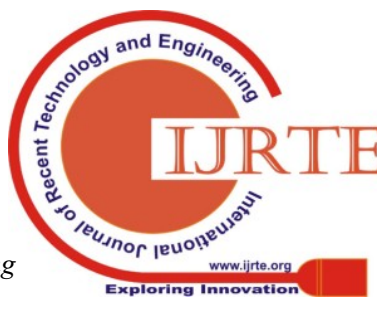


18. Klasa, Adrienne (2018) "Round-tripping: how tiny Mauritius became India's main investor ", October 30th, 2018, Financial Times, London

19. Loyens \& Loeff NV (2018) "Holding Regimes (2018): Mauritius compared to other jurisdictions"http://bizweek.mu/fr/info/holding-regimes-2018-mauritiu s-compared-other-jurisdictions

20. Ministry of Finance and Economic Development, Budget Speech 2018-19, Mauritius http://budget.mof.govmu.org/budget2018-19/2018_19budgetspeech.pd $\mathrm{f}$

21. ODI (2017) Why do Development Finance Institutions use offshore financial centres? Overseas Development Institute,

ttps://www.odi.org/publications/10967-why-do-development-finance-i nstitutions-use-offshore-financial-centres

22. PIB (2019) Ratification of the Multilateral Convention to Implement Tax Treaty Related Measures to Prevent Base Erosion and Profit Shiftinghttp://pib.nic.in/PressReleaseIframePage.aspx?PRID $=1574095$

23. Sekar, KR and Priya Narayanan (2016)"India-Mauritius tax treaty amendment: What could be the impact on key stakeholders", May 16, 2016, Financial Express

24. Singh Sandeep (2016) "What the changes in the tax treaty with Mauritius mean for India, investors" May 12, The Indian Express

25. Withersworldwide(2018) Investing into India: Mauritius and beyond

https://www.withersworldwide.com/en-gb/insight/article/pdf/4568

26. Wolters Kluwer (2019) Maurituis Tax Treaty, accessed on 21st July 2019 https://www.lowtax.net/information/mauritius/mauritius-tax-treaty-intr oduction.html 